\title{
Perineuronal Glial Nets in the Rat Spinal Cord. A Golgi Study
}

\author{
Guillermo Bodega, Carmen Gianonatti, Isabel SuAREZ ${ }^{1}$ \\ and Benjamín FERNANDEZ ${ }^{2}$
}

Cátedra de Citología e Histología Vegetal y Animal ${ }^{1}$, Facultad de Ciencias, Universidad de Alcalá de Henares, Alcalá de Henares, y Facultad de Ciencias Biológicas, ${ }^{2}$ Universidad Complutense, Madrid, Spain

Received October 16, 1985

Summary. Perineuronal glial nets in the rat spinal cord were studied. According to the density of the nets and the thickness of the processes which form them, different types of nets were demonstrated. In addition to nets originating from microglial cells, nets formed by smooth protoplasmic astrocytes are also described.

The perineuronal glial nets were discovered by RAMón y CAJAL $(1890,1897,1898)$ and were also described and studied by his contemporary researchers, NISSL (1898), GolGI (1898), Bethe (1899) and Donaggio (1901).

The perineuronal glial nets attracted special interest, as they had great significance in discussions between reticularists and neuronists. In spite of this initial interest they received little attention during the following years; even today the cellular types forming the nets, and their functions remain poorly known.

The neuronal surface, with the exception of the synaptic zones, is surrounded by astrocytes (RAmón y CAJAL, 1909-11; PolaK, 1965; KING, 1968; SpaceK, 1971, 1980; Palay and Chan-Palay, 1974; Fernandez et al., 1984), oligodendrocytes (ScharenberG, 1954; King, 1968; Peters et al., 1970) or microglial cells (Río Hortega, 1920; ScharenberG, 1954; Murabe and SANo, 1982). Until the 1980's, a specific cellular glial type was not related to the perineuronal glial nets: BRAUER et al. $(1982,1984)$ found nets originating from microglial cells, whereas LAFARGA et al. (1984) found them formed by protoplasmic astrocytes.

The aim of this work is to further clarify the structural details of the glial nets in the rat spinal cord, as well as an inquiry into the possibility that these nets can be formed of different glial cells.

\section{MATERIAL AND METHODS}

Adult rats (Rattus norvergicus) of both sexes were used in our study. The animals were anesthetized with ether, and the spinal cord was removed as described by MEIKLE and MARTIN (1981).

The spinal cord was immediately introduced into the fixative fluid (chloral hydrate 


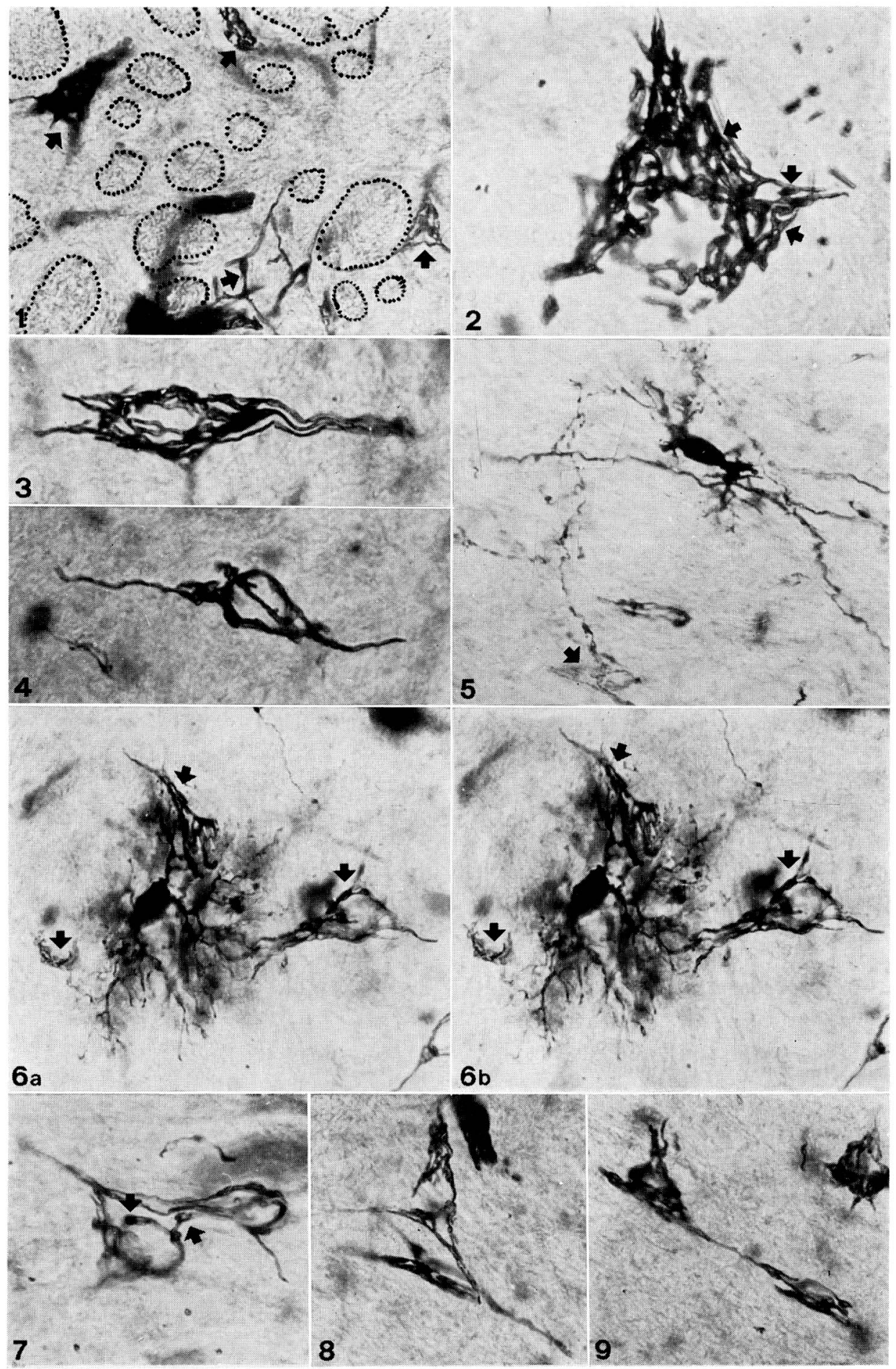

Fig. 1-9. Legends on the opposite page. 
$3 \mathrm{~g}$, potassium dichromate: $3 \mathrm{~g}$, formaldehyde: $50 \mathrm{ml}$ ) for $48 \mathrm{hrs}$ at room temperature. This fixative fluid was changed twice a day.

After fixation, the pieces were immersed without washing into a $1 \%$ silver nitrate solution, for $48 \mathrm{hrs}$. Subsequently, the pieces were transferred to absolute alcohol for $24 \mathrm{hrs}$ before their inclusion in paraffin. Transversal sections were cut at $40 \mu \mathrm{m}$, dehydrated in absolute alcohol, toluol and mounted in Depex. The nets were photographed in a Zeiss III RS Photomicroscope.

\section{RESULTS}

In the rat spinal cord astrocytes and perineuronal glial nets were observed. These nets were located in the medullar gray matter (ventral horn, dorsal horn, and intermediate gray) and even the neurons of the reticular formation were surrounded by them (Fig. 1).

The thickness of the glial net processes and their density changed according to the zone of the gray matter considered. According to certain characteristics we found the following three types of nets: The first type was dense nets formed by thick processes of $0.7-1.2 \mu \mathrm{m}$ thick (Fig. 2), and related to motor neurons: these nets were found only in the ventral gray matter; the second type consisted of dense nets formed by thin processes about $0.6 \mu \mathrm{m}$ thick (Fig. 3); they surrounded the large and middle neurons. They were frequent in the ventral horn and in the intermediate gray, but were rare in the dorsal horn. The last type of net was located in the intermediate gray and the dorsal horn. These nets were loose and the processes which composed them were about $0.6 \mu \mathrm{m}$ thick (Fig. 4).

The thickness of the processes in any given net was not constant; there were zones or nodes in which the nets became wider (Fig. 2,7). The nets surrounded the neuronal soma and also followed the first part of the processes, becoming looser (Fig. 3).

The cell type which formed these nets was not determined. However, we obtained evidence that, in the spinal cord, at least two cellular types could generate these net. The microglial cell was one of these cellular types (Fig. 5): it sent long and thin processes which seemed to form loose nets. The other cell type, called smooth protoplasmic astrocytes (Fig. 6a, b), seemed to originate from nets with thicker processes and it was located closer to the neuronal soma than the first type.

It seemed that the soma of the cell which originated the net was not necessarily

Fig. 1. Perineuronal glial nets (arrows) in the reticular formation. The encircled zones are transversely cut axons. $\times 550$

Fig. 2. A dense perineuronal net with thick processes. The arrows show widenings in the processes of the net. Ventral horn. $\times 900$

Fig. 3. Dense perineuronal net with thin processes. Intermediate gray matter. $\times 800$

Fig. 4. Lax perineuronal net. Dorsal horn. $\times 850$

Fig. 5. Microglial cell forming perineuronal net (arrow). Intermediate gray matter. $\times 675$

Fig. 6. a and b. Smooth protoplasmic astrocyte (different focussing). Their processes from three perineuronal glial nets (arrows). Intermediate gray matter. $\times 625$

Fig. 7. A process participating in the formation of two nets. The arrows show widenings in the processes of the net. Dorsal horn. $\times 700$

Fig. 8. A process participating in the formation of three closed nets. Intermediate gray matter. $\times 650$

Fig. 9. Nets formed by the same process located some distance from each other. Dorsal zone in the ventral horn. $\quad \times 700$ 
located close to the neuronal soma, as it can be seen in Figures 5, 6a and 6b; it can be located at a considerable distance.

No evidence could be obtained indicating that one net was formed by two different cellular types. Processes which participated in the formation of two or three different nets (Fig. 7, 8), some of which were far from each other, could be found (Fig. 9). This implies that the same cell can be engaged in the formation of more than one net or at least a part of different nets.

\section{DISCUSSION}

Perineuronal glial nets have been described in the telencephalon (RAMón Y CAJAL, 1897; BRAUER et al., 1982), diencephalon and mesencephalon (BRAUER et al., 1982), cerebellum (RAMÓN y CAJAL, 1890; LAFARGA et al., 1984), as well as in peripheral ganglia (BETHE, 1899).

The structure of the perineuronal glial nets is similar for all zones studied in the central nervous system; the only difference is the thickness of the processes. RAmón Y CAJAL (1898) described them as between 0.4-1.0 $\mu \mathrm{m}$ thick, but BRAUER et al. (1982) found processes whose thickness varied between $0.2-0.4 \mu \mathrm{m}$. These differences may be due to the different staining methods used, the different zone of the nervous system studied, the size of the neurons surrounded by these nets, or the different cellular type which form the net. The clearest structural difference was noted by DonAGGio (1901) who described fine processes extended to the centre of the holes of the net, making an enlargement in this center.

The extension of the nets, so far as to surround processes which emerge from the neuronal soma, was described by RAMÓN y CAJAL (1898), DonNAGgio (1901) and BRAUER et al. (1982). RAMón y CAJAL (1898) who was able to observe the net as well as the neuron due to the staining method used, asserted that these nets never continued in the axon.

LAFARGA et al. (1984) found nets related to only large sized neurons, but we observed nets surrounding neurons of different sizes; the structure of the net varied according to the size of the neurons.

It has been well known that astroglial cells are in close relation to neurons (RAMÓN y Cajal, 1909-11; Polak, 1965; Spacek, 1971; Palay and Chan-Palay, 1974; Fernández et al., 1984). However, it was only LAFARGA et al. (1984) who described perineuronal nets formed by astrocytes.

The relation of microglia to the neuronal elements has also long been known. Río HorTEga (1920) suggested that microglia could be a neuronal satellite surrounding the neurons to form a basket, or it could be located far from the neurons sending processes to form the mentioned basket. He also affirmed that one of these neuronal baskets could be formed by different cell processes. Scharenberg (1954) attributed to the microglial cells the ability to form perisomatic nets. Murabe and Sano (1982) found that the microglial processes could isolate the synapsis. Finally, BRAUER et al. (1982) obtained the clearest correlation between perineuronal nets and microglia, concluding that the microglia could form at least two different nets.

Oligodendrocytes are also able to form perisomatic nets (SCHARENBERG, 1954), or at least to be in relationship with neurons (KING, 1968), although DE CASTRO (1946) reported that oligodendrocytes neuronal satellites did not tend to surround either the neuron or its dendrites. 
RAMÓN-MOLINER (1958) described cells in the cortex of the cat, considering them to be oligodendrocytes. He gave them an intermediate-form role between the protoplasmic astroglia and the oligodendroglia, naming them "mossy oligodendrocytes." The relationship between these intermediate cellular types and the neuronal somas has also been described by KING (1968). PALAY and CHAN-PALAY (1974) described astrocytes with long and smooth processes and called them "smooth protoplasmic astrocytes."

In our observations, some nets originate from this glial type, the smooth protoplasmic astrocyte. BRAUER et al. (1982) did not deny that the nets could be also formed by other glial cellular types.

The function assigned to these nets has changed in course of time. GolGI (1898) assigned them a nutritional role. Bethe (1899) and NissL (1898) considered them a reticulated fibrilary apparatus related to an intersticial network of nervous fibers in the gray matter. RAMÓN Y CAJAL (1898) considered them an apparatus formed by the vacuolization of the ammonium molybdate used in the staining method. DonagGio (1901) and Held (1902, cited by BRAUER et al.) were the first researchers to assign these nets a glial origin, considering them factors of stabilization. BRAUER et al. (1984), studying chemical compounds of the nets, assigned to them a role related to the nervous transmission into the sympathetic system. LAFARGA et al. (1984) concluded that the holes of the nets were places where synapses were settled, and ascribed them functions of controling the synaptic transmission. Whatever the function of these nets may be, it is not specific of a determined glial cellular type because, astroglia (HERTZ, 1981; Arenander and de Vellis, 1981; Henn, 1982), oligodendroglia (Friede, 1965; Peters et al., 1970) and microglia (MURABE and SANO, 1982) have been physiologically known to be related to neurons.

Acknowledgements. We are grateful to Antonio Priego for his technical assistance.

\section{REFERENCES}

Arenander, A. T. and J. De Vellis: Glial-released proteins: III. Influence on neuronal morphological differentiation. Brain Res. 224: 117-127 (1981).

Bethe, A.: Über die Neurofibrillen in der Ganglienzelle von Wirbelthieren und ihre Beziehungen zu den Golginetzen. Physiol. Inst. Univ. Strassburg: 513-526 (1899).

Brauer, K., L. Werner and L. Leibnitz: Perineuronal nets of glia. J. Hirnforsch. 23: 701-708 (1982).

Brauer, K., G., Bruckner, L. Leibnitz and L. Werner: Structural and cy tochemical features of perineuronal glial nets in the rat brain. Acta histochem. 74: 53-60 (1984).

De Castro, F.: Sobre el comportamiento y significación de la oligodendroglía en la substancia gris central y de los gliocitos en los ganglios nerviosos periféricos. Arch. Histol. normal patol. 3 : 317-343 (1946).

Donaggio, A.: Sulla presenza di sottili fibrille tra le maglie del reticolo periferico nella cellula nervosa. Rev. Sperim. Freniatr. 27: 127-132 (1901).

Fernandez, B., I. Suarez and G. Gonzales: Topographical distribution of the astrocytic lamellae in the hypothalamus. Anat. Anz. (Jena) 156: 31-37 (1984).

Friede, R. L.: Enzyme histochemistry of neuroglia. Prog. Brain Res. 15: 35-48 (1965).

Golgi, C.: Intorno alla struttura delle cellule nevose. Bolet. Soc. Med.-Chir. Pavia. 1: 1-16 (1898).

Held, H.: Über den Bau der grauen und weissen Substanz. I. Zur Kritik der pericellulären Netze der Ganglienzellen. Arch. Anat. Entw.-Gesch (Leipzig) Jg. 1902: 189-224 (1902).

Henn, F.: Neurotransmitters and astroglia lead to neuromodulation. Chemical transmission in the 
brain. Progr. Brain Res. 55: 241-152 (1982).

Hertz, L.: Functional interactions between astrocytes and neurons. In: (ed. by) E. Acosta Vidrio and S. Fedoroff: 11th Int. Congr. Anat., Part A: Glial and neuronal cell biology. Alan R. Liss, Inc., New York, 1981 (p. 45-58).

King, J. S.: A light and electron microscopic study of perineuronal glial cells and processes in the rabbit neocortex. Anat. Rec. 161: 111-125 (1968).

Lafarga, M., M. T. Berciano and M. Blanco: The perineuronal net in the fastigial nucleus of the rat cerebellum. A Golgi and quantitative study. Anat. Embriol. 170: 79-85 (1984).

Meikle, A. D. S. and A. H. Martin : A rapid method for removal of the spinal cord. Stain Technol. 56: 235-237 (1981).

Murabe, Y. and Y. Sano: Morphological studies on neuroglia. V. Microglial cells in the cerebral cortex of the rat, with special reference to their possible involvement in synaptic function. Cell Tiss. Res. 223: 493-506 (1982).

Nissl, F.: Nervenzellen und grauen Substanz. Münch. med. Wochenschr. 31-33: 1-47 (1898).

Palay, S. L. and V. Chan-Palay : Cerebellar cortex: cytology and organization. Springer-Verlag, New York, 1974.

Peters, A., S. L. Palay and H. de F. Webster: The fine structure of the nervous system. The cells and their processes. Hoeber-Harper and Row, New York, 1970.

Polak, M.: Morphological and functional characteristics of the central and peripheral neuroglia (Light microscopical observations). Prog. Brain Res. 15: 12-34 (1965).

Ramón y Cajal, S.: A propos de certains élémentis bipolares du cervelet. Int. Monatschr. Anat. Physiol. $7:$ 13-23 (1890).

: Las células de cilindroeje corto de la capa molecular del cerebro. Rev. Trim. Micrográf. II: 105-127 (1897).

-: La red superficial de las células nerviosas centrales. Rev. trim. Micrográf. III: 199-204 (1898).

: Histologie du système nerveux de l'homme et des vertébrés. Vol. I, II. C.S.I.C. Reimp, Madrid, 1909-11 (p. 1952-1955).

Ramón-Moliner, E. : A study on neuroglia. The problem of transitional forms. J. comp. Neurol. 110: 157-171 (1958).

del Río Hortega, P.: El tercer elemento de los centros nerviosos. I. La microglia en estado normal. Bol. Soc. Esp. Biol. Año IX, Vol. VIII: 68-82 (1920).

Scharenberg, K.: Blastomatous oligodendroglia as satellites of nerve cells. Amer. J. Pathol. 30: 957-969. (1954).

Špaček, J.: Three-dimensional reconstructions of astroglia and oligodendroglia cells. Z. Zellforsch. 112: 430-442 (1971).

Dr. Guillermo Bodeg A

Cátedra de Citología e Histología Vegetal y Animal

Facultad de Ciencías

Universidad de Alcalá de Henares

Alcalá de Henares, Madrid, Spain 